\title{
Lithuanian Pension System'S Reforms Transformations and Forecasts
}

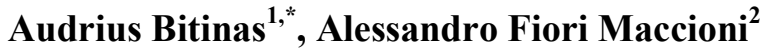 \\ ${ }^{1}$ Department of Business Law,Mykolas Romeris University, Vilnius, Lithuania \\ ${ }^{2}$ Department of Economics and Business (DiSea), University of Sassari, Italy and CRENoS, Sardinia, Italy \\ *Corresponding Author: audriusb@mruni.eu
}

Copyright $@ 2014$ Horizon Research Publishing All rights reserved.

\begin{abstract}
The aim of this article is to describe the Lithuanian pension system, its reform process and its long-term financial sustainability. We define therefore the current reforms in the public pension system, influenced by the last economic crisis and social challenges. Also, we forecast the financial dynamics of the public pension system, in the light of raising social expenses (due to second pillar pension reforms) and of demographic trends (like ageing society and low fertility). Results reveal the long-term sustainability of the system, albeit at a cost of initial negative balances to be covered with public budget. Policy solutions could improve sustainability by encouraging and extending employment (especially for the disadvantaged) and by building trust in both public and private pension systems.
\end{abstract}

Keywords Lithuanian Pension System, Public Budget, Population and Actuarial Forecasting

\section{Introduction}

Before the economic crisis in 2008, Lithuania reformed pension system in 1995 and 2003. Lithuania's pension system model is based on classical Bismarkian principles (earning related benefits and ensured state's guarantees) and from 2002 to 2008 had social security fund budget surplus.

Pension expenditures in Lithuania in 2007 was only 6,8\% of GDP and it was almost twice lower than an average of EU-27 (11,8\% of GDP in 2007): this is due to a more favorable population structure and to the fact that in the pre-crisis rapid economy growth period pensions have increased at a lower pace than the GDP. Without any pension reform the replacement rate (male worker retiring at 65 after 40 years of career) in the first pillar will decline from $48 \%$ to $35 \%$ in 2048 (European Commission. The Joint report on pensions, 2010, p. 88).

Pension expenditures in Lithuania will grow: the change of the age-related expenditure in 2007-2060 will be $4,6 \%$ of GDP (in EU-27 will be $2,4 \%$ of GDP in the period 2007-2060). Despite of negative prognosis showing increase of the pension expenditure in Lithuania, there are some factors which could mitigate the growth of the pension system expenses: restriction of the eligibility for a public pension (through higher retirement age, reduced access to early retirement and changes of the disability pension system), higher employment and reduced generosity of pensions (European Commission. The Ageing report, 2009).

According to the projections of the Eurostat and Lithuanian Ministry of Social protection and Labour, the population of Lithuania will decline to 2,5 million from 2009 to 2060 , the elderly population (aged 65 and older) will more than double from $16 \%$ to $32,7 \%$. Lithuania has one of the highest negative rates of crude migration (net) in EU-27 ( $-4,6 \%$ in Lithuania and $1,9 \%$ in EU-27) (European Commission. Joint report on pensions, 2010, p. 87). However, in Lithuania we could fix still relatively high employment of the older workers (55-64 years): the employment rate of older workers in 2009 was higher $(51,6 \%)$ than the average of EU-27 (46\% in 2009) (European Commission. The Ageing report, 2009).

The pace of pension reform has accelerated over the period 2007-2010 and changes include increases in pensionable ages, the introduction of automatic adjustment mechanisms and the strengthening of work incentives. Some countries have also better focused public pension expenditure on lower income groups. However, some recent reforms have raised controversy, such as the decision of some central and eastern European countries to pull back earlier reforms that introduced a mandatory funded component (OECD, 2012, p. 15-18).

Lithuania sharply affected by the economic crisis. In Lithuania (according to the data of Lithuanian statistics institution) GDP declined from 2,9\% (in 2008 ) to minus $14,7 \%$ (in 2009) and economic growth returned only in 2011; unemployment rate raised from $5,8 \%$ in 2008 to $17,8 \%$ in 2010; employment rate (15-64 ) declined from $64,3 \%$ to $57,8 \%$. According to the Eurostat data, public sector debt grown from $15,6 \%$ of GDP (2008) to $38,2 \%$ in 2010 .

Today we could underline common challenges to be met by Europe'ssocial security systems: demands for more personal choice and quality improvements in services and 
benefits; the impacts of globalization (greater flows of people, goods, services and capital across national borders); population ageing and economic, fiscal and social fallout of the currenteconomic crisis (International social security association, 2010, p. 93). M. Ferrera emphasized that a genuine European invention, public protection schemes were introduced to respond to the mounting "social question" linked to the industrialization and the disruption of traditional, localized systems of work-family-community relations and the diffusion of national markets (based on free movement and largely unfettered economic competition within the territorial borders of each country) profoundly altered the pre-industrial structure of risk and need (Ferrera, 2010, p. 45).

When we are searching for the better efficiency of the social security system and higher social security coverage, it is important to note, that social security structure depends on the type of social model. Today it is difficult to find pure social model, designed in the classic Bismarck or Beveridge tradition, but the essential elements of a theoretical model still dominates. The strengths of Continental model (France, Germany) could be: mandatory participation in the social insurance system; the right to social security benefits is related to the paying of social insurance contributions; relatively high benefits; indexation related to the economic situation; autonomous management of the system; social insurance contributions are related to the social insurance risks. The weaknesses of this model are: complexity of the system; the system is not fully universal; the system do not guarantee minimum level of benefits. The strengths of Anglo-Saxon model (United Kingdom, Ireland) are: universality; free medical care; the system includes all needs of person. The weaknesses are the following: relatively low level of benefits; medical care (financed by taxes) coverage depends on the economic situation; the biggest role is given to the additional voluntary private systems. The strengths of Nordic model (Scandinavian countries) are: universality (wide coverage); extremely high benefits; the minimum level of benefits is established; the public social insurance depends on the contributions paid; large public confidence in the system; equality between women and men. The weaknesses of this model are the high cost of the system and high level of social insurance contributions (Kahil-Wolff, B., Greber, P. Y., 2006, p. 47-49).Eastern European social model (Lithuania) characterized by both Nordic social model features (active labour market policies),Continental model (the structure of the social security system) and the Anglo Saxon features (development of private initiatives and labour market liberalization policy). Development of Eastern European social model is related to the fact, that countries in this region changed economic orientation from socialist to market-oriented system. But we could point out, that the economic transformation (increased unemployment, poverty, inequality, bankruptcies of companies and industries, fiscal crisis, creation of new public institutions) and other related facts (the needs of different social groups, recommendations of international institutions, European integration) resulted in the limited public financial resources. G. Esping Andersen argues, that the Eastern European countries have opted for a liberal social security system concept, where the basis of social security schemes have been privatized, reduced social security coverage, social assistance is based on the means-testing principle and labour market is flexible (Esping-Andersen, G., 1996, p.20).

In this perspective, wepresent the Lithuanian pension system and its reforms. Also, we give a qualitative and quantitative evaluation of its sustainability in the light ofcurrent economic and demographic trends. We conclude with an agenda of further reforms. The paper starts with thepresentation of Lithuanian pension system (Sect. 2) and its reforms (Sect. 3). It continues with the forecasting of Lithuanian public pension system (Sect. 5). Finally, conclusions are drawn (Sect. 6).

\section{Pension System's Reforms in the Light of the International Organisations}

European Commission noted that the purpose of automatic adjustment mechanisms is to maintain the balance between revenues and liabilities in pension schemes, and these mechanisms impact on both intergenerational adequacy and sustainability. These mechanisms imply that the financial costs of demographic changes will be shared between generations subject to a rule. To a varying degree they link: i) life expectancy to pension eligibility or replacement rates; ii) economic performance in terms of GDP growth or labour market performance (with valorisation of entitlements or indexation of benefits); iii) balance of the system to valorisation of entitlements or indexation of benefits and contribution rates with indexation of benefits (European Commission. Joint report on pensions, 2010).

Organisation for Economic Co-operation and Development(OECD, 2012, p. 15-18) stressed, the crisis has accelerated pension reform initiatives, while private pension policy makers have focused their attention on regulatory flexibility and better risk management; the introduction of automatic adjustment mechanisms in public pension systems will improve their sustainability, but may raise adequacy problems; the coverage of funded, private pensions is insufficient in some countries to ensure benefit adequacy; return guarantees are generally unnecessary and counterproductive but in some countries they may be justified in order to protect pension benefits and raise public confidence and trust in the private pension system; a new roadmap for defined contribution pension plans: policies to strengthen retirement income adequacy.

Analysis shows that while some of the losses incurred during the crisis may be recovered during economic recovery relatively quickly, a complete restoration of pension finances may take many years (it means that people have lost a 
number of years of savings due to the financial crisis) and might not recover during their remaining active life (because of vulnerability of pension levels in defined contribution schemes) (International Labour conference, 2011, p. 61).The crisis has wiped out years of economic and social progress and exposed structural weaknesses in Europe's economy, the world is moving fast and long-term challenges: globalization, pressure on resources and ageing (European Commission. Communication "Europe 2020", 2010). Because the public pension replacement rates in general declined in the EU, reforms have given and will continue to give rise to greater individual responsibility for outcomes and it is important to provide sufficient opportunities for complementary entitlements: e.g. enabling longer working lives and increasing access to supplementary pension schemes (European Commission. Green paper, 2010).

International Labour organization (ILO) notes, that the repercussions that these developments will have on contributors and pensions are not straightforward, and will most likely affect people who retire after the crisis butpensions funds in 2008 in many countries suffered enormous losses during the global crisis. OECD emphasized that countries private pension funds lost $23 \%$ of their value in 2008 . The degree of vulnerability of future pension levels to the performance of capital markets and other economic fluctuations, introduced in so many pension systems during the last three decades, was clearly a mistake that stands to be corrected. Strong minimum pension guarantees may work here as "automatic stabilizers" of retirees' living standards. Response to the economic crisisis only possible on the basis of existing administrative structures, that is, existing social institutions which either can automatically react to changing economic conditions thanks to their design, or can be easily adjusted (e.g. extended) to crisis-induced requirements (International Labour Office. World's social security report, 2010, P. 106-118). European Commission in the White paper "An agenda for adequate, safe and sustainable pensions" indicated that member states should: create i) link the retirement age with increases in life expectancy; ii) restrict access to early retirement schemes and other early exit pathways; iii) support longer working lives by providing better access to life-long learning, adapting work places to a more diverse workforce, developing employment opportunities for older workers and supporting active and healthy ageing; iv) equalise the pensionable age between men and women; v) support the development of complementary retirement savings to enhance retirement incomes (European Commission. Green paper, 2010).

When revenue is declining, the simplest way to regulate the social insurance fund budget is to increasestate social insurance contributions or to reduce benefits. However, these methods cannot be applied as the fastest economic effect because they indirectly impact State's competitiveness and employment policy. Reduction of pension benefits may affect certain undesirable legal and social implications, raise the questions of social solidarity, social security unity, benefits differentiation and legitimate expectation principles.
Thus, the reduction of pensions means that persons are not encouraged further work and expect a higher pension, and pensions will decline despite of paid higher social insurance contributions. The economic crisis and reduction of pensions, deny the contribution-benefit balance and it's important to maintain the state social insurance pension guarantees. Reduction of pensions could violate mainprinciple of Bismarck social tradition: the benefits depend on paid contributions.

\section{Pension System's Reforms in Lithuania}

The last economic recession strongly impacted Lithuanian pension system reforms. From 1 July 2009, the amendments to the Lithuanian Pension system reform law adopted: the state social insurance contributions transfers to the private pension funds fallen to $2 \%$ and social insurance benefits reduced for two years. On 28 October 2009, a National Agreement was signed between the Government of the Republic of Lithuania and social partners: the largest trade unions, business and employers as well as pensioners' organizations. Under this Agreement, the Government undertook to implement measures for financial consolidation, including a temporary reduction in all pensions (except the smallest pensions). Therefore, the government reduced pension benefits in 2009 (however, the Lithuanian Constitutional Court decided, that reduced part of pensions must be compensated in the future). Only in 2010 a complex pension system reforms adopted and future policies designed.

\subsection{Reference Literature and Scientific Research}

The tendencies of welfare state development, financing and pension system's reforms in Lithuania are analysed by A. Guogis, R. Lazutka, T.Medaiskis, P.Gylys.

A. Guogis, D. Bernotas analysed the social models and development of the welfare state (Guogis, Bernotas, 2006). P. Gylys states that the experience of some East European states showed that contributory funded pension schemes were established without deep analysis of the reform consequences and the reform results were worse than forecasted (Gylys, 2002). Evaluating 2003 pension system reform, R. Lazutka points out that primary objective of the pension reform was the state protection for corresponding businesses not for private individuals who failed to understand that participation in those pension schemes could hardly ensure more social safety (Lazutka, 2007). According to A. Guogis, such a solution of pension system problems only recedes (but not approaches) a vision of "social Europe" still further (Guogis, 2004).

The development of Lithuanian pension system after latest economic crisis of 2008, problems of the pension adequacy and financial stability, pension system evolution and related modelling is new approach in the scientific 
literature. The results of scientific analysis and transformations forecasts showed the Lithuanian pension system's financial stability perspective. This study and conclusions shows the directions for the future pension system's reforms in Lithuania.

\subsection{Purpose of Reforms}

Pension system's reforms should cover not only the traditional measures (to reduce benefits and to increase contributions), but should be donetogether with the comprehensive social security system and labour law reform: to grow the employment, to introduce more flexible labourforms andactive labour market policies, to review the system of social security benefits (reduce or eliminate some benefits), to introducehealth social insurance contributions for pensions (pensions are taxable in many EU countries, except Lithuania).Economic Cooperation and Development Organization in the pensions review of 2009 noted, that in the face of the economic crisis, the government adopts the short-term practical solutions, meanwhile, long-term strategic plans, which are important to pensioners' incomes, are ignored (OECD, 2009). ILO indicated that the short-term responses to a crisis - macroeconomic stabilization, trade policies, financial sector policies and social security - cannot ignore longer-term implications for both economicdevelopment and vulnerability to future crises (International Labour Office, 2010, p. 112). International social security association noted (International social security association, 2013), that the last three years have seen a number of reform measures taken, not least to respond to longer-term trends and changes in the demographic and social environment and more immediate fiscal pressures heightened by the crisis. The danger is that significant reforms (e.g. raising the retirement age) are being made without the coherent development of a necessary cross-sectoral policy strategy (e.g. employment, return-to-work, and occupational safety and health policies to support employment among older workers), and without a fuller national debate involving all relevant social partners and stakeholders about the likelihood of necessary further reform.

The time for reforms is actually critical:without the prolongation of retirement age and without incentives for the private pension accumulation, the deficit of state social insurance fund will be higher and the trust of the societyin social insurance system could fell down.

\subsection{Pension System Reform in 2003}

In 2000,the Government of the Republic of Lithuania adopted the Concept of the Pension system reform. This Concept indicated the principal goal - to change the pension system in such way, that personsat the retirement age could get higher pension income, the pension system should become more viable and would cover all population as well as the redistribution effect in the systemshould be decreased.
Concept stated that quasi/mandatory funded pension system will be introduced (without increasing contribution rate for the pension insurance).It should be mentioned that the Concept has been adopted at the time of economic and social crisis: existing deficit of the state social security fund,economic recession, declining demographic situation.

The Concept provides also that the first level (pillar) of pension system of Lithuania should guarantee the state social security pension (retirement, disability, widows and orphans). The second level (pillar) is quasi/ mandatory funded pensions operated by the private pension funds. The third stage (level) of the pension system is an additional voluntarily funded pension system (operated by pension funds or life insurance companies).

In July 2003 the Parliament adopted a Law on Funded Pensions. This law provides, that from 1 January 2004 the part of the contributions will be transferred to the private pension funds (if person decides to participate). The reasons to introduce funded pension system were deterioration of demographic situation, sustainability of the pension system and the surplus of the state social security budget.

Social insurance contribution rate to the funded system fixed by $2,5 \%$ for the first year and increased every year by $1 \%$ to $5,5 \%$ maximum. There were no restrictions for participation by age (below the legal retirement age). The supplementary part of the state social insurance old-age pension reduced in proportion to the size of the contribution rate.

The participants of the funded pension system can receive accumulated benefits at the retirement age. The volume of the accumulated sum depends on the annuity period, transferred contributions, investment results and the level of administration costs of the pension funds. Every year pension funds must inform participants about the accumulated sum.

Law on Funded Pensions defined, that lack of finances in the budget of social security (because of transferred contributions to the private funds) should be financed from the state property privatization and from the state budget.Each year the Law on the Approval of Indicators of the Budget of the State Social Insurance Fund provides the compensation level for the state social fund.

Participation in the funded pension system was active; however this may be related to the Government incentives explaining in mass media positives points to accumulate.Relatively high part of the older population (from 45 year)accumulates in this funded pension system (about $28 \%$ of total population in 2010).About $85 \%$ of the social insurance system's participants decided to accumulate for the funded pension in 2010 .

Economic crisis strongly influenced the funded pension system. The state social pension insurance contributions (which are transferred to the pension funds) were reduced from 5,5 to $2 \%$ in $2009-2011$.

The introduction of the funded pension system in 2003 means, that Lithuanian pension system turned into Anglo-Saxon model: the state social security system become 
partly dependent on the state budget and participants of the funded pension system have less state guarantees from the first pension's pillar.

\subsection{Pension System Reforms after Economic Crisis}

Economic crisis and analysis (indicated in the Concept of the reform of state social insurance and pension scheme of 15 June 2010) showed that there are several problems in pension insurance: the current benefit scheme enables the duplication of benefits; the redistributed part of social insurance pensions (the basic pension) has great significance for the pensions level, while the impact of contributions paid by a person is reflected insufficiently. It makes this scheme unattractive; benefits are not linked to the life expectancy; no incentives to continue longer work career; the identification of work incapacity and special needs are insufficiently transparent and controlled; the state social insurance scheme is financially vulnerable and thepension reserve fund not established; the indexation of the pension benefits is not linked to theeconomic and demographic indicators and is under a strong political impact; no long-term strategy for thepension accumulation.

On 15 June 2010, the Concept of the reform of state social insurance and pension scheme has been approved. The goal of the reform is to establish financial sustainability, to guarantee adequate and target-oriented benefits and to administer pension system more efficiently. In this concept some proposals has been fixed: to increase the pensionable age for women and for men until 65 years of age for the both genders in 2027;to cancel new state pensions (not related with the insurance record); to introduce private pension's fund better management means;to pay non-contributory social insurance pensions from the state budget; to apply a new clearer formula for pensions; to introduce economic indexation of pensions; to change the formula ofthe social insurance old-age pension calculation, introducingaccounting units ("points") system or to introduce notional pension system;to integrate state pensions into the general scheme of social insurance.

The Lithuanian Parliament reached a wide political agreement and on 24 May 2011 adopted Guidelines of pensions and social security reform. The Government adopted theMeasures plan for implementation of Parliament Guidelines (adopted in Government on June 8, 2011) and timetable for thepreparation of the laws projects.

The reform will last in two stages. The transitional period will start since 2012 and will last until 2026. Second stage will start form 2027.

The main aim of the reform as indicated in the Guidelines, is to ensure that persons could receive adequate pensions, to stabilise the state socialinsurance fundbudget and to adjust the pensions level to to theeconomical and demographical changes. Several principles indicated in the Guidelines:

1. More transparency in the pension system - pension system participants should receive all information about pension rights, should know about system' benefits and should be constantly notified of the obtained rights to the state social security pension.

2. Separation of the social insurance and social assistance: better correlationbetween contributions and benefits; to make labour market more flexible; to increase gradually a retirement age; pension's level should be related to the demographic and economic situation; government should encourage employment of elderly persons.

3. To establish clear indexation rules and clear relationship between social insurance fund and state budget. The pension benefits indexation should belinked to the economic and demographic, but not to the political indicators. Others changes related to the new pension formula: to transfer the basic flat-rate pension to the state budget and to introduce NDC (virtual accounts) system or accounting units ("points") system.

4. To cancell privileged benefits in future, to integrate all state privileged pensions into the social insurance system and to create professional pension funds.

5. Better regulation and more efficiency in second pillar private funded pension schemes. Theaccumulation in the second pillar gradually should be restored and voluntary pension accumulation should be encouraged. Themeasures for the better management of the pension funds should be introduced: introduction of the life-cycle investment system; to analyze the possibility to introduce state pension fund etc.

E.Volskis stressed (Volskis, 2012), that as response to growing demographic risks due to low fertility, life expectancy increase, risks related to migration of working age population and shortening of employment services period all three Baltic countries have introduced successfully the new pension systems, which established good pre-conditions to mitigate aforementioned risks. Nevertheless financial crisis in 2008 and 2009 and currently ongoing crisis in euro zone countries indicated that the pension systems in Baltic countries were not properly protected against the real economic risks, which were related to long term unemployment and decrease of return rates below inflation rates, for instruments such as term deposits and government bonds, which historically were considered no risk financial investments with stable returns of $4-5 \%$.

Council of the European Union noted (Council of the European Union, 2013), that the adequacy of pensions is a challenge as the older population is at a high risk of poverty and exclusion. The 2012 reform of the pension accumulation system encourages 2 nd pillar pension accumulation with financial incentives from the state budget. It also introduces the possibility to opt out from private pension accumulation and return to the state social insurance fund during a transitional period as well as a gradual increase of retirement age. These are important but isolated steps in the right direction and more significant changes are needed, particularly within the 1 st pension pillar. In addition, measures that promote the employability of older workers 
and age friendly working environments are necessary.

\subsection{Prolongation in the Retirement Age}

The increase of the pensionable age is strongly related to the longer life-expectancy. One of the key recommendations of European Unionis prolongation of pensionable age and changes in the pre-retirement pension schemes. Prolongation of pensionable age is common process in many European countries because of state social security pension system vulnerability, ageing and raising of life expectancy. In the European Union's startegy “Europe 2020: Integrated guidelines for the economic and employment policies of the member states" is indicated that, member states should emphasize promoting increased labour force participation through policies to promote active ageing (European Commission, Strategy “Europe 2020”, 2010).

International social security association noted (International social security association, 2013), that raising the retirement age, and thus pushing back the age at which benefits can be taken, can also support the financial sustainability of pension systems by encouraging continuing contributions from insured employment and reducing the duration for which benefits are likely to be paid out on average. In addition, a later retirement age may support efforts to improve benefit adequacy by allowing a longer period of accrual of benefits.

On June 9, 2011 the Parliament approved the amendments to the Law on state social insurance pensions and it was decided to increse the retirement age. The retirement age will be increased by 4 months per year for women and 2 months per year for men from 2012, until it reaches 65 years in 2026 . This decision was adopted with regard to the longer lifespan after the retirement age. According to the data from the Department of Statistics of Lithuania, in 2009 the average life expectancy after 65 years of age in Lithuania was 13.38 years for men and 18.25 years for women. According to the Eurostat projections, in future the life expectancy will grow (19years for men and 22,6 years for women in 2050).

\subsection{Accumulation for the Retirement Pension in the Second Pillar}

Private schemes can relieve some of the pressure on public pension provision, however, increasing reliance on private schemes has fiscal costs, given the widespread practice of providing tax incentives during the accumulation phase (European Commission. Green paper, 2010).International Labour Organization indicated thatwhere the schemes were financed collectively and have been fully managed by State (in particular through PAYG financing), the immediate impact has been small. In contrast, fully funded schemes, where individual savings have been invested in relatively volatile products, have sustained severe loses.States should implement following principles: regular actuarial studies, establishment of contingency reserve or stabilization funds and strict investment rules (International Labour Office,
2011, p. 183).

On 14 November 2012, the Parliamentapproved the changes in the funded pension scheme. The aim was to create opportunities for current and future retirees to decide how they would like to accumulate their pensions in future. According to the newregulation, from 2014the financial sources for the second pilar will consist from three parts: the contribution transferred from state social insurance fund budget, contribution paid from person's earnings and subsidy from the state budget.

There are three posibilities for persons. First,person could accumulate pension under current conditions, when $2 \%$ ofstate social insurance contribution's part is transferred from state social insurance fund to the private funds. The current contribution rate will remain until 2020 (since 2020 , the contribution rate will be increased from $2 \%$ to $3.5 \%$ ). Second, the person could pay additional 1\% (from $2016-2 \%$ ) from his earnings to private pension fund and $2 \%$ (from 2020-3,5\%) ofsocial insurance contribution's part will be transferred from state social insurance fund to the private funds. In order to encourage a person to accumulate in private funds, the state will financially encourage person:in this otion, the subsidy from the state budget $(1 \%$ from an average wage in the national economy from 2014 and $2 \%$ from 2016) will be transferred from the state budget to a person's pension account. Additional 1\% will be transferred from the state budget for every child until three years. Third, during transitional period (from 1 April 2013 to 30 November 2013), persons have a possibility to stop the participation in the pension fund and toreturnto thestate social insurance fund.

\section{Forecasting the Evolution of Lithuanian Public Pension System}

\subsection{Methodology}

In this section we evaluate the long-term financial sustainability of Lithuanian public pension system, in the light of current demographic, financial and regulatory changes. Our model follows the traditional actuarial approach, widely adopted in Pension Economics. The interested reader can find technical references in Janssen and Manca (Janssen, Manca, 2006), Booth et al. (Booth et al., 2006), Hyndman and Booth (Hyndman, Booth, 2006), Pitacco (Pitacco, 2004, p. 279-298). Classic introductions to forecasting national population, which may be useful for the inexperienced reader, are the contributions of Leslie (Leslie, 1945, p. 183-212) and of the United Nations (United Nations, 1956). Other quantitative analyses of the Lithuanian case have been proposed by Klyvienè (Klyviené, 2004) and Alho (Alho, 2002).

We start by estimating the life dynamics of national population divided by gender and age. We make a forty-year prediction, from 2012 to 2051, and we consider the 
demographic variables of mortality, fertility and migration. Then, we analyze the working conditions of national population in the forecasting period. We find initial contributors and pensioners and we forecast their life dynamics. Each year, new cohorts of workers enter in the pension system, while some existing cohorts fulfill the pension requirements and retire. We calculate for each cohort of workers the cash inflows for contributions to the pension scheme, and for each cohort of pensioners the cash outflows from the pension scheme. The annual difference between total contributions and pensions determines the pension balance. The annual pension balances accrue over the forecasting period and determine the evolution (and the eventual sustainability) of the pension scheme. We estimate the financial evolution of the pension system under three scenarios, which correspond to the three possible individual choices of contribution of Lithuanian workers according to current reforms (see section 3.6 and figure 1). Also, we estimate the effects of the reform on the monthly income of future pensioners (see figure 2). Finally, we define a minimum and a maximum range of variation for the financial evolution of the public pension system, according to the results in the different scenarios (see figure 3).

\subsection{Demographic Model}

We calculate the evolution of population divided by gender, age and working conditions, with the following formulae. Let $P O P_{s x}(y)$ represent the national population of gender $s=\{F, M\}$ and age $x$, alive at year $y$. For $x \geq 1$, we estimate the national population as:

$$
\begin{gathered}
P O P_{s x}(y)=P O P_{s x-1}(y-1) \cdot\left[1-\frac{q_{s x-1}(y-1)+q_{s x}(y-1)}{2}-\right. \\
m s x-1 y-1+m s x y-12,
\end{gathered}
$$

where $q_{s x}(y)$ and $m_{s x}(y)$ represent, respectively, the mortality rate and the net migration rate at year $y$ of individuals with gender $s$ and age $x$.

For $x=0$, we estimate the national newborn population as:

$$
P O P_{s x=0}(y)=\sigma_{s} \cdot \sum_{x}\left[\Phi_{x} \cdot P O P_{s=F x}(y-1)\right],
$$

where $P O P_{s=F x}(y)$ is the national population of females aged $x$ at year $y$, the value $\Phi_{x}$ is the annual fertility rate of women aged $x$, and $\sigma_{s}$ is the share of newborn babies of gender $s=\{F, M\}$, with $\sigma_{F}=1-\sigma_{M}$.

Let $N_{s \times a}(y)$ represent the population of members of the pension system alive at year $y$ of gender $s$, age $x$ and seniority in the system $a$. Given a population of existing members $N_{s x_{a}}(y)$ with $a>1$, we estimate its evolution as:

$$
N_{s x a}(y)=N_{s x-1 a-1}(y-1) \cdot\left[1-\frac{q_{s x-1}(y-1)+q_{s x}(y-1)}{2}\right],
$$

where $\mathrm{q}_{\mathrm{sx}}(\mathrm{y})$ represents the mortality rate at year $y$ of individuals with gender $s$ and age $x$.

We estimate new members as follows. We assume that all new contributors enter in the pension system at age $x=\bar{x}$ and we estimate the population of new contributors $N_{s \times a}(y)$ with $a=1$ and $x=\bar{x}$ as:

$$
\begin{aligned}
N_{s x=\bar{x} a=1}(y)= & \sum_{x}\left[P O P_{s x}(y-1) \cdot \alpha_{s x} \cdot\left(1-\beta_{s x}\right)\right] \\
& -\sum_{x a} N_{s x a}(y-1),
\end{aligned}
$$

where $\alpha_{\mathrm{s} x}$ and $\beta_{\mathrm{s} x}$ represent, respectively, the activity rate and the unemployment of population with gender $s$ and age $x$. The preceding formula tends to keep unchanged over time the activity and unemployment rates among the population.

\subsection{Financial Model}

Let $c_{g s x a}(y)$ be the average contribution of type $g$ paid at year $y$ by a member of sex $s$, age $x$ and working seniority $a$, determined as:

$$
c_{\text {gsxa }}(y)=\gamma_{\text {gxay }} \cdot R_{\text {gsxa }}(y)
$$

where $\gamma_{\text {gxay }}$ and $R_{\text {gsxa }}(y)$ represent respectively the contribution rate and the expected financial amount (i.e. gross income) for the determination of the contribution type $g$ due at year $y$ by an individual of sex $s$, age $x$ and seniority $a$.Then, the annual cash flows at year $y$ for contributions to the pension system is equal to:

$$
\begin{gathered}
C_{y}=\sum_{g} \sum_{s} \sum_{x} \sum_{a} c_{g s x a}(y) \cdot N_{s x a}(y), \\
\forall(x, a) \in N \times N-\left\{x>\hat{x}_{d s y} \wedge a \geq \hat{a}_{d s y}\right\},
\end{gathered}
$$

where $\hat{\mathrm{x}}_{\mathrm{dsy}}$ and $\hat{\mathrm{a}}_{\mathrm{dsy}}$ represent respectively the retirement requirements of age and seniority, in force at year $y$, for members of sex $s$ to be entitled to a benefit of type $b$. Thus, the $\mathrm{N}_{\mathrm{sxa}}(\mathrm{y})$ considered in the previous equation are cohorts of active members. The term $c_{\text {gsxa }}(y)$ is the average contribution of type $g$ paid at year $y$ by an individual of sex $s$, age $x$ and seniority in the pension system $a$. The term $g \in G$ represents a generic contribution of all the existing types of contributions $\mathrm{G}$.

The annual pension disbursement at year $y$ is equal to:

$$
\begin{gathered}
B_{y}=\sum_{d} \sum_{s} \sum_{x} \sum_{a} b_{d s x a}(y) \cdot N_{s x a}(y), \\
\forall(x, a) \in N \times N:\left\{x>\hat{x}_{d s y} \wedge a \geq \hat{a}_{d s y}\right\},
\end{gathered}
$$

where $\hat{\mathrm{x}}_{\mathrm{dsy}}$ and $\hat{\mathrm{a}}_{\mathrm{dsy}}$ represent the retirement requirements of age and seniority, in force at year $y$, for members of sex $s$ to be entitled to a benefit of type $d$. Thus, the $\mathrm{N}_{\mathrm{s} \times \mathrm{a}}(\mathrm{y})$ considered in the previous equation are cohorts of retired members of the pension system alive at year $y$ of gender $s$, age $x$ and seniority $a$. The term $\mathrm{b}_{\mathrm{dsxa}}(\mathrm{y})$ is the average benefit of type $d$ received at year $y$ by a pensioner of sex $s$, age $x$ and working seniority $a$. The term $\mathrm{d} \in \mathrm{D}$ represents a generic benefit of all the existing types of benefits D.

Let $V_{y}$ represent the cumulated balance of the pension system, which we model with the following recursive equation:

$$
V_{y}=V_{y-1} \cdot\left(1+r_{y}\right)+C_{Y}-B_{y}-E_{y}
$$

wherer $_{\mathrm{y}}$ is the nominal annual interest rate on public debt, $\mathrm{C}_{\mathrm{y}}, \mathrm{B}_{\mathrm{y}}$ and $\mathrm{E}_{\mathrm{y}}$ represent respectively the amounts of 
contribution income, pension disbursement and administrative expenses generated in the year $y$. All of the cash flows are assumed to take place at the end of each year.

\subsection{Demographic, Financial and Pension Assumptions}

We adopted the forecasting model described in section 4.2 under the following demographic assumptions:

- Population of Lithuanian pensioners and contributors at $1^{\text {st }}$ January 2012, divided by sex, age and seniority, estimated from data of Lithuanian Official Statistics Portal.

- Future new contributors enter in the pension system at age 25 .

- Mortality rates estimated as a function of official Lithuanian values in 2011 and their average rates of change in 1975-2011, by gender and age (data retrieved on 19-09-13 from the Human Mortality Database of the Max Planck Institute for Demographic Research and the University of CaliforniaBerkeley, at www.mortality.org).

We adopted the forecasting model described in section 4.3 under the following financial assumptions:

- Annual pension balance equal to collected contributions minus pensions minus the eventual governmental subsidy to $2^{\text {nd }}$ pillar accounts (see scenario $B$ in section 4.5).

- We consider an annual management cost for the public budget of 42 million Litas in nominal values at 2012, appreciated annually by inflation.

- We assume that the overall social security budget deficit at $1^{\text {st }}$ January 2012 is 5 billions Litas, appreciated annually at $3.65 \%$ interest rate (that is the average interest rate on Lithuanian bonds in August 2013, source European Central Bank).

- Inflation rate equal to European Central Bank long-term objective, thus equal to $2,00 \%$.

- Annual gross incomes, for each cohort of same sex and age, equal to average values in 2010 published by the Lithuanian Official Statistical Portal, appreciated at nominal GDP growth rate in 2011-2012 and at 3,00\% for the following years.

We estimated the old-age insurance public pensions under the following assumptions:

- Benefits paid to pensioners who retired before $1^{\text {st }}$ January 2012 estimated according to average values in 2012, published on Lithuanian Official Statistics Portal.

- Pensioners who retire after $1^{\text {st }}$ January 2012 get an old-age insurance pension consisting of three components: a basic sum; a supplement based on working seniority; an earnings-related part, calculated with an accounting unit ("points") system and reduced proportionally to second pillar contributions.

- Pensions after $1^{\text {st }}$ January 2012 estimated for each cohort of members by gender and age, according to current regulations.

- All pensions are appreciated annually at inflation rate. Each cohort of contributors retires immediatly after fulfilling requirements. We do not consider benefit reversion to survivors.

\subsection{The Contribution Regimes: Three Scenarios}

In estimating the financial dynamics of the Lithuanian public pension system, we considered the current reform of second pillar system (exposed in section 3.6) that requires workers to choose among three different contributive options. Lithuanian regulations allow for two types of contributions: to $1^{\text {st }}$ pillar public pension system and to $2^{\text {nd }}$ pillar pension system. In the period 2004-2013 (before the reform produces its effects) we adopted for every worker the contemporary contribution rates. In the period from 2014, we considered the three contribution regimes that have been introduced with the reform (see section 3.6). We considered three scenarios in which every worker choose to join the same contributory regime:

A) contribution rate to $1^{\text {st }}$ pillar equal to $24,3 \%$ in years 2014-19 and to $22,8 \%$ from 2020 . Contribution rate to $2^{\text {nd }}$ pillar equal to $2 \%$ in years $2014-19$ and to $3.5 \%$ from 2020.

B) Contribution rate to $1^{\text {st }}$ pillar equal to $24,3 \%$ in years 2014-19 and to $22,8 \%$ from 2020.Contribution rate to $2^{\text {nd }}$ pillar equal to $3 \%$ in years $2014-15$, to $4 \%$ in years 2016-19 and to 5.5\% from 2020. Additional governmental subsidy to $2^{\text {nd }}$ pillar of $1 \%$ of average national salary in years 2014-15 and of 2\% from 2016.

C) Contribution rate to $1^{\text {st }}$ pillar equal to $26,3 \%$ of gross income; no contribution to $2^{\text {nd }}$ pillar system.

We assume that $2^{\text {nd }}$ pillar private pension funds generate $3.00 \%$ annual returns in period 2004-13 (as their average I.R.R.in same period, published by Lithuanian Central Bank) and 3.65\% returns from 2014 (as the average interest rate on Lithuanian bonds in August 2013, published by European Central Bank). Existing workers already contributed to the $2^{\text {nd }}$ pillar system for various years (those aged 29 or older have contributed since 2004; those aged 22-28 since their were 21 ). New workers enters immediately in the $2^{\text {nd }}$ pillar system. Private annuities have been calculated at the retirement year by applying to the accrued contributions the regulatory conversion rates for 2012, fixed by Lithuanian Central Bank. We assumed that every cohort of pensioners converts their $2^{\text {nd }}$ pillar contributions into annuities.

\subsection{Results}

We estimated the financial dynamics of the Lithuanian public pension system and the effects of demographic, economics and regulatory variables in the period 2012-2051. We made three different forecasts according to the three scenarios described in section 4.5. In every scenario, the Lithianian public pension system is sustainable in the long term, even if the state bugdet should bear an initial negative balance. The rebalancing of the system happens at a cost of low pension payments, especially for oder cohorts of current workers. 
Annual pension balances for each scenario are shown in Figure 1. Negative pension balances are initially observable and their persistence can vary. If all contributes flowed into the first pillar public system, as in scenario $\mathrm{C}$, the annual public pension balance would turn positive in 2017. Conversely, if the Government subsidized every second pillar private account, as in scenario $\mathrm{B}$, the annual pension balance would turn positive in 2026 .

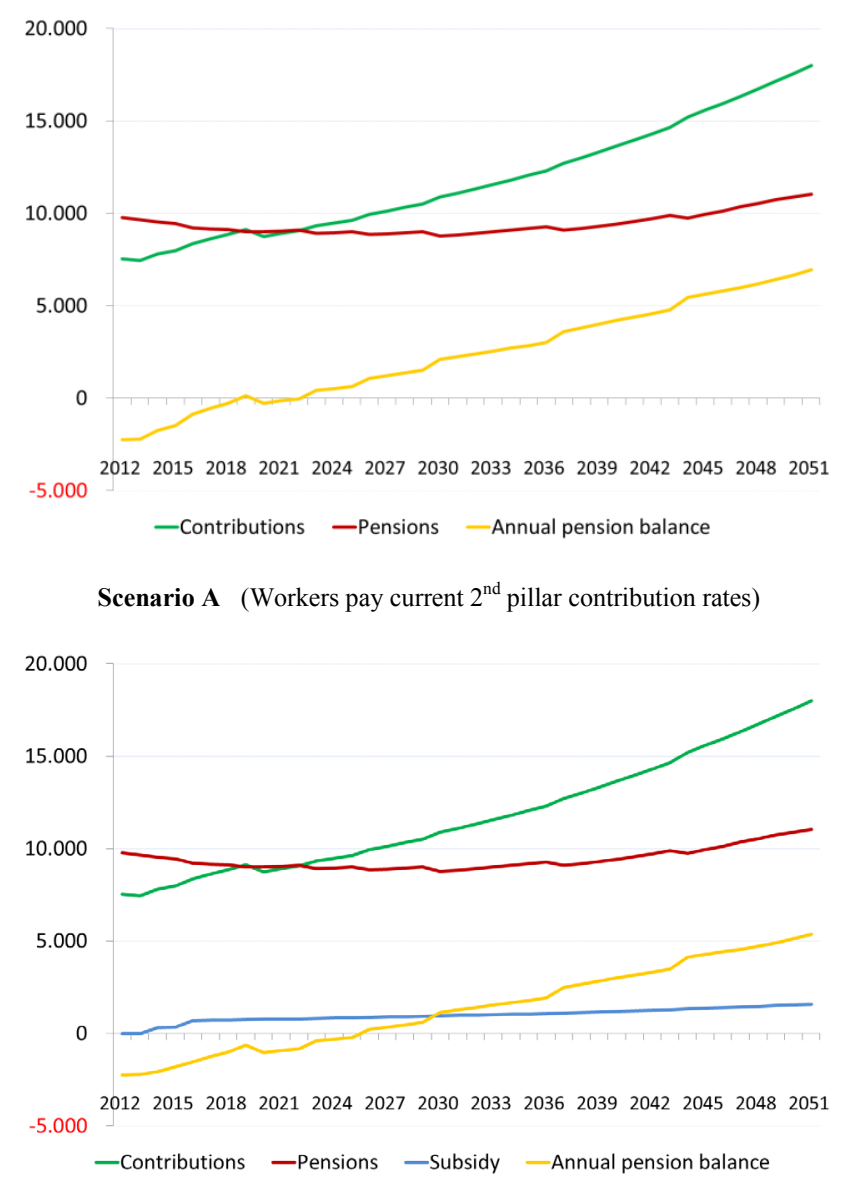

Scenario B (Workers pay higher contribution rates and Government subsidies the $2^{\text {nd }}$ pillar)

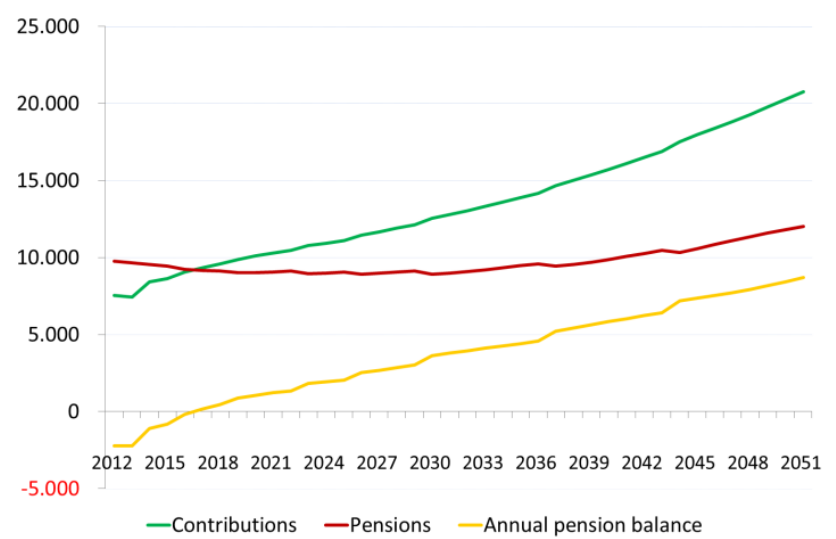

Scenario C (Workers exit from $2^{\text {nd }}$ pillar system)

Figure 1. Lithuanian public pension system: forecasting of annual balances, years 2012-51 (annual nominal values in million Litas)
In figure 3 we show the cumulated pension balances over the forecasting period under the three scenarios. The overall deficit of the public pension system is completelly cancelled in 2027 under the favourable scenario C, and in 2043 under the less favourable scenario B. We can consider scenarios B and $\mathrm{C}$, respectively, as the maximum and minimun range of variation of future results. Then, we deduce that the cumulated balance of the public pension system will turn positive between 2027 and 2043 (see figure 3) according to the workers' choices of contribution regime. This result suggests that current pension reforms guarantee the long-term sustainability of the public pension system.

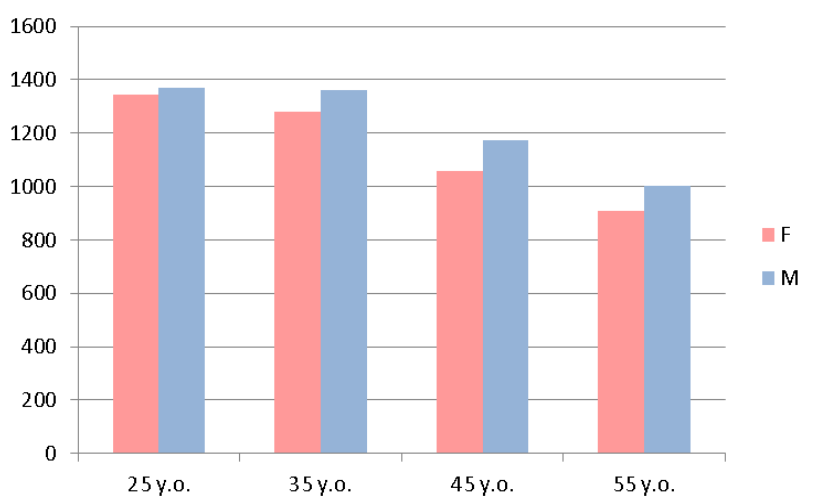

Scenario A (Workers pay current $2^{\text {nd }}$ pillar contribution rates)

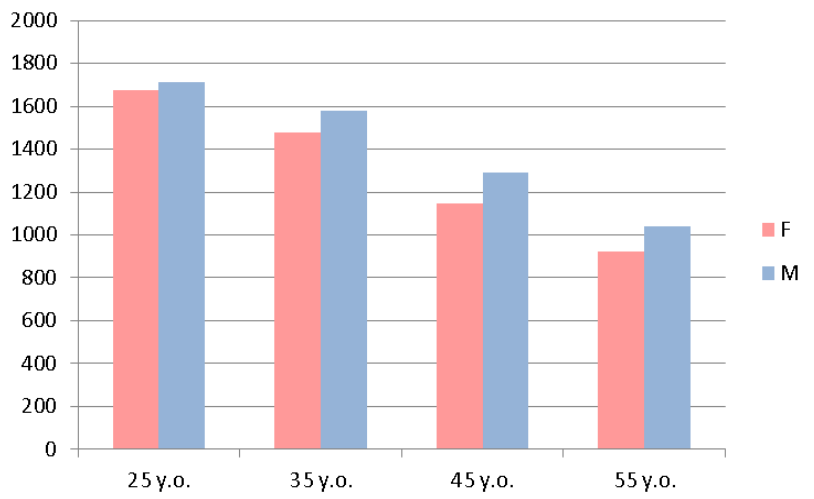

Scenario B (Workers pay higher contribution rates and Government subsidies the $2^{\text {nd }}$ pillar)

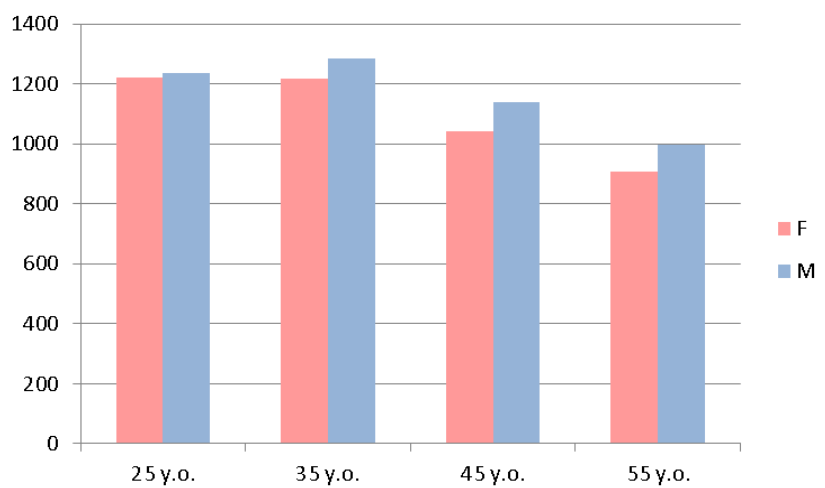

Scenario C (Workers exit from $2^{\text {nd }}$ pillar system) 
Figure 2. Average monthly pension for different age cohorts of females and males (real values in Litas at 2012 prices)

Figure 2 suggests that long-term sustainability is reached through low pension payments. Figure 2 shows the average monthly pension for different age cohorts, in real values at 2012, depending on the worker's choice of contribution regime. The most favourable choice is the option $\mathrm{B}$ because it implies a public subsidy to their private second pillar account. The advantage of option B is higher for younger workers and decreases according to age. In all scenarios, pension provisions seem low and may expose to the risks of poverty and social exclusion; this is true especially for females and older workers.

Forecastings should be considered with caution because the model cannot capture the effects of abrupt demographic and economic changes. Improvements in accuracy can be obtained with wider statistical data. Further quantitative analysis of the Lithuanian pension system would require a risk assessment through stress testing and percentile analyses.

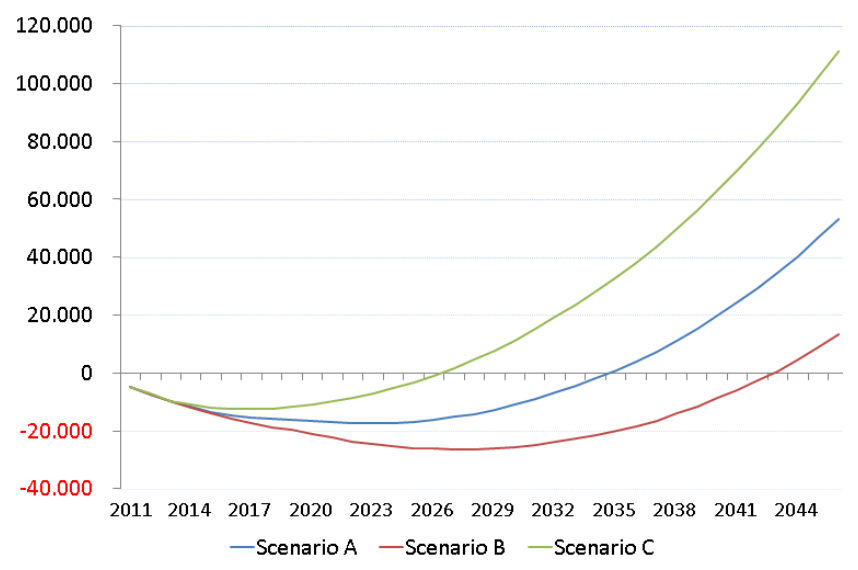

Figure 3. Lithuanian public pension system: forecasting of cumulated pension balances, years 2012-51 (annual nominal values in million Litas).

\section{Conclusions}

The paper has presented the Lithuanian pension system, its reforms and an evaluation of its sustainability in the light of current economic and demographic trends. The quantitative analysis reveals its long-term tendency towards financial equilibrium, albeit at a cost of initial negative balances to be covered with public budget. The system may expose workers to risks of poverty and social exclusion because of low pension payments. The problem is higher for old workers, which can benefit less from second pillar pension savings. Article analysis leads to the following conclusions:

1. The key policy is to rebuilt the trust in public social insurance schemes and in private funded pension schemes. Participants of the private and public pension system should be constantly and clearly notified of the obtained pension rights.
2. Therefore, the concept of social security should cover public state security schemes, state funded second pillar pensions and all private funded or occupational pension schemes. Social insurance pension calculation of the replacement rate should comprise not only public pensions but statutory private quasi/mandatory funded pensions (second and third pillar).

3. The challenges for the Lithuanian pension system is ageing population (especially low fertility rate), low employment rate, low pension's benefits, poverty of older persons, no clear indexation rules, emigration and growth of the pension expenditures.

4. Pension system has to respond directly to the changes in the structure of society and must be very closely related to the flexibility of labor relations (part-time or half-day employment, opportunities for longer and less interrupted contributory careers, the positive returns from financial markets, more lifelong learning etc.), creation of better working conditions and the changing the approach of employers towards older workers.

5. It is necessary to intensify the pension system's reform in Lithuania because of sharpening of the demographic and social changes. The main goals should be: to encourage and extend employment (especially for the older workers, women and young persons), to revise all social security system benefits; to balance the budget of the social security fund and to introduce pension reserve fund; to decrease pension funds administrative costs; to introduce pension benefits indexation rules; to reform unemployment system and to reduce the early retirement pension system (intruding flexible retirement); to introduce an automatic adjustment mechanisms; to maintain the balance between revenues and expenses in the pension system.

\section{REFERENCES}

[1] Alho, J.M. (2002). Stochastic forecast of the Lithuanian population 2001-2050. Project Report. Helsinky: The Research Institute of the Finnish Economy.

[2] Booth H., Hyndman R.J., Tickle, L., De Jong, P. (2006): Lee-Carter mortality forecasting: a multi-country comparison of variants and extensions. Demographic Research, Vol. 15, pp. 289-310.

[3] Council of the European Union (2013). Recommendation for a Council recommendation on Lithuania's 2013 national reform program and delivering a Council opinion on Lithuania's convergence program for 2012-2016, No. $10643 / 1 / 13$.

[4] Espig-Andersen, G. (1996). Welfare states in transition. After the Golden Age? Welfare state dilemmas in a global economy. London: Sage Publications, 1996, p. 20. 
[5] European Commission (2010). Communication from the Commission Europe 2020: A strategy for smart, sustainable and inclusive growth. European Commission, Brussels, 2010.

[6] European Commission (2010). Europe 2020: Integrated guidelines for the economic and employment policies of the member states. European Commission, Brussels, 2010.

[7] European Commission (2010). Green paper: towards adequate, sustainable and safe European pension systems. European Commission, $\operatorname{COM}(2010) 365$ final, Brussels, 2010.

[8] European Commission (2010). Joint report on pensions: Progress and key challenges in the delivery of adequate and sustainable pensions in Europe (country profiles). EPC Secretariat, SPC secretariat, Brussels, 2010.

[9] European Commission (2009).2009 Ageing Report: Economic and budgetary projections for the EU-27 member states (2008-2060). European Economy, vol. 2, 2009.

[10] Ferrera, M. (2010).Mapping the components of Social EU: a critical analysis of the current institutional patchwork. In Marlier, E. and Natali, D. (eds.). Europe 2020: Towards a more social EU? Work and Society No. 69, P.I.E. Peter Lang S.A, Brussels, 2010.

[11] Hyndman R.J., Booth H. (2006): Stochastic population forecasts using functional data models for mortality, fertility and migration. ANU Working Papers in Demography, No. 99, 2006.

[12] Guogis, A., Bernotas, D. Globalizacija, socialinė apsauga ir Baltijos šalys. MRU, Vilnius, 2006.

[13] Guogis, A. Globalizacijos poveikis socialinei apsaugai ir socialinei atskirčiai. Politologija. 2004, No. 4.

[14] Gylys, P. Reforms of pension system in Lithuania. Ekonomika. 2004, No.66.

[15] International Labour conference „Social security for social justice and a fair globalization“. International Labour Office, Geneva, 2011.

[16] International Labour Office (2010). World's social security report 2010/2011: providing coverage in times of crisis and beyond. International Labour Office, Geneva, 2010.

[17] International Labour Office (2011). Social security and the rule of law: general survey concerning social security instruments in light of the 2008 Declaration on social justice for a fair globalization (ILC.100/III/1B). International Labour Office, Geneva, 2011.

[18] International social security association (2010). Dynamic social security for Europe: choice and responsibility: developments and trends. International social security association, Geneva, 2010.

[19] International social security association (2013). Europe: enhancing the sustainability of comprehensive social security systems. International social security association, Geneva, 2013.

[20] Janssen, J., Manca, R. (2006). Applied Semi-Markov Processes. Springer, New York

[21] Kahil-Wolff, B., Greber, P. Y. (2006).Sécurité sociale: aspects de droit national, international et éuropéen. Bruxelles: Helbing\&Lichtenhahn, 2006.

[22] Klyvienè, V. (2004). The Public Debt and the Problem of Population Ageing in Lithuania. Available at SSRN: http://ssrn.com/abstract=2070664

[23] Lazutka, R. Pensijų sistemų raida Lietuvoje. Filosofija, sociologija. 2007, No. 2.

[24] Leslie, P.H. (1945) "The use of matrices in certain population mathematics".Biometrika, 33(3), 183-212.

[25] Organisation for Economic Co-operation and Development (2011), Pensions at a Glance 2011. Retirement - income systems in OECD and G20 countries, OECD publishing, 2011.

[26] Organisation for Economic Co-operation and Development (2012), Pensions outlook, OECD publishing, 2012.

[27] Pitacco, E. (2004). Survival models in a dynamic context: a survey. Insurance: Mathematics and Economics, 35, 2, 279-298

[28] United Nations (1956). Manual III. Methods for population projections by sex and age (United Nations publication, Sales No. 56.XIII.3).

[29] Volskis, E. Reforms of Baltic States pension systems: challenges and benefits, Tallin, 2012. Available at: http:// http://ebrd.com/downloads/news/pension-system.pdf 